\title{
Epilogue: Changing Archaeological Perspectives upon Historical Ecology in the Pacific Islands ${ }^{1}$
}

\begin{abstract}
Atholl Anderson ${ }^{2}$
Abstract: Late-twentieth-century archaeological perspectives upon historical ecology in the Pacific islands emphasized anthropogenic impacts documented particularly in studies of vegetation change and deforestation, and the depletion or extinction of native faunas. More complex views of cultural-environmental relationships are now emerging. Biological invasions are seen as occurring more variably than in the transported landscapes model, simplistic narratives of cultural collapse are shown as only partly in agreement with relevant data, and models of behavioral ecology are argued as insufficient to explain long-term trajectories of ecological change. More influential roles are being proposed for climatic and demographic factors and cultural agency in ecological relations.
\end{abstract}

IN CONSIDERING HOW archaeological perspectives upon historical ecology are changing it is instructive to glance at Historical Ecology in the Pacific Islands (Kirch and Hunt 1997), which collated papers from a session of the 17th Pacific Science Congress in 1991. The main sessional themes that emerged from the contributions were natural versus anthropogenic change, anthropogenic impacts on island ecosystems, environmental evidence of human colonization (seeking anthropogenic environmental data), reciprocal impacts of environmental change and human society, and fragility versus resilience of island ecosystems. Clearly, the principal emphasis of these was the crucial influence of long-term human impacts, many deleterious, on the histories of island ecosystems, a topic largely absent from the otherwise highly influential Man's Place in the Island Ecosystem (papers from the 10th Pacific Science Congress [Fosberg 1963]), to which the genesis of a modern Pacific island historical ecology is largely, and rightly, at-

${ }^{1}$ Manuscript accepted 27 January 2009.

2 Department of Archaeology and Natural History, Research School of Pacific and Asian Studies, Australian National University, Canberra ACT 0200, Australia (e-mail: atholl.anderson@anu.edu.au).

Pacific Science (2009), vol. 63, no. 4:747-757

(C) 2009 by University of Hawai'i Press

All rights reserved tributed. Although the historical significance of people in shaping Pacific island ecosystems remains at the core in the current collection of papers, a more complex understanding of that is now emerging, or so it seems to me. I comment here on three topics discussed in papers from the 21st Pacific Science Congress that suggest new emphases in Pacific historical ecology: biological invasions, landscape history, and behavioral ecology. The Pacific islands, often taken as cognate with "Oceania," include here the Pacific offshore islands of the Americas, which have their own distinguished record of research in historical ecology.

\section{BIOLOGICAL INVASIONS}

Although earlier emphases in historical ecology, especially in Oceania, were upon faunal depletions, extirpations, and extinctions (e.g., Anderson 1997, Steadman 2006), and important as these are, much of the recent work has been directed at understanding the arrival, spread, and influence of domesticated and commensal animals and plants. The regional diversity of such taxa around the Pacific Rim, in different subsistence combinations adapted to varied landscapes and climates throughout the Holocene, throws into contrast the situation in the mainly tropical Oceanic islands where the same basic package of Southeast Asian-New Guinea items (pig, dog, fowl, plus commensal rats [principally 
Rattus exulans], taro, yam, breadfruit, and banana) was spread across the vast region of Remote Oceania $<3,000$ B.P. (the archipelagos lying generally east of the main Solomon Islands). The broad ethnographic similarity of subsistence economies in that region has given rise to a notion of serial replication of agricultural landscapes, the "transported landscapes" model of Anderson (1952), adopted by Kirch (1982; cf. "portmanteau biota" of Crosby [1986:89]). The transported landscape was conceived as an integrated package of root and tree crops, plus domestic scavengers, that was re-created, island by island, through frequent long-distance voyaging. These two features of transported food production plus accomplished voyaging underwrote migration success and created interacting colonies of metapopulations (in the ecological terms of Lindenmayer and Fisher [2006:57]). But to what extent can this model be validated archaeologically?

Research on the prehistoric introduction of domesticated plants has been slow to develop because of the difficulty of recovering and identifying material remains. Pollen from taro, for example, although identified from a number of sites in Hawai'i, has never been found at prehistoric levels in sedimentary cores from New Zealand, although taro occurred in both archipelagos at European arrival (Prebble and Wilmshurst 2008). Macroremains, such as dessicated tissue or charcoal from taro, sweet potato, and other crops, have seldom been identified, and the sample of sweet potato tissue thought oldest in Polynesia (Hather and Kirch 1991) has still not been radiocarbon dated directly. A number of recent papers (e.g., Horrocks and Bedford 2005, Horrocks and Weisler 2006) have used starch analysis to propose the existence of various domesticated plants in archaeological sites across Oceania. These claims would be more plausible and encouraging if the comparative collections used to identify the starch had included material from other than domesticated plants.

Research on faunal introductions has a larger database, yet it is difficult to compile comprehensive and precise data on the introduction patterns. The overall impression emerging in Remote Oceania is that although there is an ethnographically recognized complex of introductions its formation was varied in time and fragmented in space. Tropical islands close to the western margins of $\mathrm{Re}$ mote Oceania, through which fauna were introduced, obtained more taxa (fowl, pig, rats) earlier; islands in the tropical belt from $\mathrm{Va}$ nuatu to the Gambiers got the same set of taxa but not always at once, and islands below the tropics or at a greater distance seldom received the full complement (e.g., New Caledonia, Rapa, and Chathams [only rat], Easter Island [fowl, rat], New Zealand [dog, rat], and so on) (Anderson 2008a). The patterns of introduction were dependent, it can be assumed, upon the "invasiveness" capability of different taxa (rats being small, fast-breeding, and needing almost no free water were best adapted of the group), the "invasibility" characteristics of different islands (movement from one tropical high island to another was more favorable than to coral islands or out of the tropics), and the efficacy of transport, the latter still being a subject of considerable debate (Anderson 2008b). The combination of these factors determined the extent of "propagule pressure" that incoming populations of alien organisms could exert, and this effect has been shown as fundamental in understanding invasion success (Colautti et al. 2006). As yet, there has been no detailed analysis of prehistoric Oceanic biological invasions in these terms, although that is an obvious next step. Currently, the unresolved debate about the nature and practice of prehistoric seafaring, and the patchy archaeological database of introduced taxa, provide little support for the transported landscapes model as a general description of Remote Oceanic biological invasions, although they do not allow its rejection.

Biomolecular research on the origins and dispersal of introduced animals in the prehistoric Pacific is a relatively new development that is improving the database and widening the scope of issues under investigation. Larson et al. (2007) have shown that, contrary to expectations derived from the prevailing "out-of-Taiwan" model of initial human (Lapita culture) entry to Remote Oceania, only the pigs that reached western Micronesia had East Asian origins, probably through 
Taiwan and the northern Philippines. All other pigs form part of a "Pacific clade," which seems to have had its origins in Southeast Asia and a dispersal route through southern Indonesia. Research on Rattus exulans, primarily by Matisoo-Smith and colleagues, has made considerable progress and also uncovered, not unexpectedly, some problems that admit of no simple answers. For example, as they discuss in this issue, Rattus exulans, which did not occur prehistorically in Taiwan, seemed to have reached Near Oceania and Remote Oceania separately, as marked in earlier research by mutually exclusive haplotypes (II and III, respectively) in each region. However, new data show that haplotype II also reached the Reef-Santa Cruz islands in Remote Oceania and that haplotype III occurs in the Near Oceanic Bismarck archipelago. Matisoo-Smith et al. propose two phases of introduction during the Lapita era (or possibly before it for introduction of haplotype II to Near Oceania). That is quite possible, especially if Lapita colonization occurred as multiple migratory events. Yet, in the frustrating absence of suitably preserved protein from rat bone samples of Lapita association, and therefore the absence of prehistoric biomolecular data, there exist alternative explanations of no less validity.

One is that the minority haplotype in each region is representative of limited post-Lapita movement. It is noticeable that haplotype II occurs only in the Remote Oceanic islands closest to Near Oceania, and that haplotype III is confined to the eastern fringe of islands in Near Oceania. It well known that there was late prehistoric interaction between the Reefs-Vanuatu and Near Oceania (Bedford 2006), and that Polynesian voyagers, probably accidentally, reached many "Polynesian outlier" islands in the West Pacific after about A.D. 500. It is quite plausible that the blurring of distributional margins in rat haplotypes reflects these processes more than it does those of Lapita colonization. It is important to balance alternative hypotheses, and, on the same theme, the assertion by Matisoo-Smith et al. that a southern interaction sphere of two-way voyaging connected New Zealand with central East Polynesia is only one proposition. Although often re- peated, it lacks supporting evidence. There is certainly evidence of a connection from central East Polynesia but none yet shown materially to East Polynesia from New Zealand, or indeed, despite similar claims, from any of the marginal East Polynesia archipelagos (Anderson 2008b).

Using data from Aitutaki Island in the Cook Islands, Allen and Craig examine in detail the manner in which introduced animals ameliorated the impact of natural hazards upon the availability of natural resources. They relate a long-term decline in fish bone deposition to coastal damage resulting from storms during the fourteenth century that continued to have an impact up to about A.D. 1600. Using $\mathrm{N}$ and $\mathrm{C}$ isotopic values from human, pig, and dog bone, they show that dietary attention moved substantially from marine to terrestrial subsistence practices. Interestingly, they also suggest that although human diets remained relatively stable, those of pigs and dogs varied considerably over time, indicating that they bore the brunt of resource deficiencies, thereby buffering the impact of those upon human communities. As Allen and Craig observe, this suggests that the diets of domestic animals, in this way more sensitive to environmental and cultural vicissitudes, might be more informative of subtle changes in subsistence fortunes than those of people. Plausible as the climatic explanation of those changes might be, Allen and Craig also allude briefly to an alternative explanation that has, I think, some persuasive power. This is that a growing population on Aitutaki compelled some changes in subsistence practice that might have been expected whether or not there were also environmental impacts. Movement from risky and less-reliable line fishing outside the reef to more-reliable and productive netting in the lagoon, and from foraging to increased agriculture, was quite probably "density dependent."

\section{LANDSCAPE HISTORY}

Landscape history has been the staple model of historical ecology for archaeologists and associated scientists (Kirch and Hunt 1997, Ladefoged and Graves 2002, Balée 2006, 
Stahl 2008). Long-term climatic and anthropogenic changes have been seen as the generative causes of landscape transformation, with only scant attention being paid to shortterm environmental catastrophes arising from severe storms, earthquakes, tsunamis, and volcanic activity. Today, however, as environmental catastrophism gnaws at the foundations of philosophical uniformitarianism and confidence wanes in the efficacy of technological, not to mention financial, instruments for the alleviation of environmental disaster, the time is ripe for serious consideration of these. Torrence et al. argue for the ecological significance of historical disaster, particularly by active vulcanism and with particular reference to the unusually active volcanics of the Willaumez Peninsula in New Britain. Given the popular characterization of the Pacific margin as "a rim of fire," and its high incidence of earthquakes and tsunamis, the case for adding catastrophic events to those of longer duration in reaching an understanding of landscape change and social consequences is beyond doubt. As Torrence et al. observe, however, events of immediate disaster were often balanced with longerterm benefits, as indeed occurs in environmental changes of other origins; volcanic eruptions produced obsidian and other valuable lithics, the replenishment of soils, and rejuvenation of forest succession.

Yet whether active vulcanism during human prehistory in the Pacific, as opposed to its geological influence, should rank considerably higher in archaeological estimation is open to debate. It has been relatively restricted in distribution through the Pacific islands, even within archipelagos where it occurred prehistorically, as in Vanuatu, New Zealand, and Hawai'i. Likewise, the role of tsunamis, devastating now in conditions of high coastal population density across the Indo-Pacific, may not have been so dramatic in prehistory. Detailed analysis of the New Zealand record (McFadgen 2006), for instance, has not produced a convincing hypothesis of catastrophic impact (Anderson 2008c). The evidence of destructive events of any origin in the period A.D. 1250-1800 (New Zealand's prehistory) is quite minor and localized, and there are considerable obstacles in the way of proposing a highly destructive tsunami as the origin of substantial changes. The radiocarbon chronology is too imprecise to specify the date of particular events within a century or more, so that their postulated extent or magnitude is indeterminable. Similar cultural changes of similar magnitude were occurring throughout New Zealand, despite a regionally differential impact of postulated tsunamis. Plausible geomorphological evidence of tsunamis is relatively minor in extent, and wider change in sedimentary regimes attributed to tsunamis has more compelling alternative explanations. Similar sequences of socioeconomic change occurred prehistorically throughout the island world, including in the Mediterranean, North Atlantic, and across the Pacific in the absence of any obvious correlations with tsunamis but, conversely, in clear association with evidence of anthropogenic landscape and resource alteration, climatic change, and population growth. Those factors, and the sheer resilience of people to natural catastrophe, cannot be cast aside lightly. Overall, it is in the nature of rapid-onset natural hazards to be fairly localized occurrences in space and time. They have been underresearched in the Pacific, and they are an important source of additional complexity in landscape history, but they did not have the almost ubiquitous and long-term impacts of climate change and anthropogenic modification.

Sea-level change is a vital issue in the landscape formation of the Pacific atolls, and it has become of greater importance in understanding the dispersal of people, plants, and animals through Oceania since the results of new research, by Dickinson (2003) in particular, plotted the extended sequence of atoll emergence into habitability across the Pacific. In a valuable case study of the interaction of atoll landscape formation and human activity, Yamaguchi et al. show that Laura islet on Majuro Atoll was able to be inhabited and cultivated soon after 2,000 B.P., during early sea-level decline from the mid-Holocene high-stand. Continuing decline brought further growth in the islet land area and in the underlying freshwater lens, with expansion 
of agricultural margins up to about 1,000 B.P. As Dickinson argues, habitation around 2,000 B.P. in the central Pacific coralline archipelagos may have reflected earlier sediment accumulation as islets than in the eastern Pacific, because of the greater tidal range. In any event, the staged sequence of atoll emergence adds greater complexity and realism to understanding the pattern of potential steppingstone islands for Pacific migration. Establishing viable communities on the atolls was, in itself, a complex business, as Thomas describes in his review of Kiribati. Atolls had unpredictable climates, poor soil fertility, especially if they lacked guano, and they were difficult to cultivate, relying mainly upon swamp taro and tree crops. Diverse and continual fishing, food preservation, population regulation, and establishment of exchange and other mobility systems were key features of sustainability.

The issue of landscape sustainability has been highlighted by continuing debate about the causes of environmental change on Easter Island, brought most widely to attention by Diamond's (2005) characterization of it as "ecocide." Hunt and Lipo argue that this is little more than a popular myth, founded in eighteenth-century conjecture and calculated to appeal to modern environmental sensitivities. It is eminently questionable. The linkage of historical patterns of deforestation to prehistoric cultural collapse in the Pacific islands (Rolett and Diamond 2004) is very uncertain. Considerable variation of late Holocene pollen profiles indicates complex trajectories toward historical vegetation patterns (e.g., substantial deforestation was delayed up to 1,000 years after human arrival in East Melanesia at 3,000 B.P., and its onset probably reflects density-dependent expansion of agriculture, whereas substantial deforestation occurred almost immediately with human arrival in much of East Polynesia about 1,000 B.P. and may reflect various factors unconsidered by Rolett and Diamond: the prevalence of very steep slopes in young volcanic islands east of the Andesite line, the effects of climatic instability with strongly increased El Niño-Southern Oscillation frequency $<1,600$ B.P., and biogeographic dif- ferences from west to east in faunal-floral coevolutionary histories. A potentially important factor, as Hunt and Lipo argue, was the impact of introduced Rattus exulans seed predation on native vegetation, including the Easter Island 7ubaea and Hawaiian Pritchardia palm forests (but see Prebble and Wilmshurst 2008).

Attributing cessation of monument construction, onset of endemic warfare, and depopulation on Easter Island to the impact of deforestation begs knowledge of chronology and causal relations that does not yet exist. As Hunt and Lipo observe, the formerly prevailing long chronology of Easter Island reflects an older belief that people reached many Pacific islands substantially earlier than can be shown evidentially (Anderson 1995, 2003a, Prebble and Wilmshurst 2008): the archaeological myth of cryptic colonization. The date at which manufacture and transport of giant stone figures ceased is unknown, and the great size of many that were uncompleted suggests that technical limitations were being reached, while changes in monumental construction and rising levels of warfare are manifested in archaeological evidence throughout late prehistoric Polynesia, whether islands were substantially deforested or not (e.g., Samoa, northern New Zealand versus Mangareva, Rapa). Furthermore, there is no indisputable evidence of prehistoric depopulation on Easter Island (Anderson 2002, Rainbird 2002), and early European estimates of 2,000-3,000 produce population densities on largely deforested Easter Island comparable with those at the same time on substantially forested Tahiti.

Last, across East Polynesia there was prehistoric settlement extinction on 24 islands, the ultimate form of cultural collapse. It shows no correlation with deforestation. Rolett and Diamond (2004) scored Nīhoa and Necker as the most deforested of their island sample, but it is unknown whether Necker was ever forested, and Nîhoa had dense Pritchardia palm forest until it was burned in 1885 (Rolett 2008). If valley-fill deposits on Nīhoa represent a phase of deforestation, then it preceded human habitation and was not caused by it. Enderby, Raoul, Norfolk, 
Phillip, and Henderson retained nearly all of their indigenous forest cover into the nineteenth century; substantial indigenous and introduced forest cover remained on Pitcairn, Suwarrow, and Palmerston, and 11 abandoned equatorial islands may not have carried much greater vegetation cover before Polynesian settlement than that which they retained at European discovery (Anderson 2002). In short, the prehistoric deforestation-cultural collapse hypothesis is not compelled empirically. Rather, it exemplifies a didactic use of islands that attained moralistic and political acuity in works by Defoe and Swift, to which status it aspires. The basic idea of insular environmental vulnerability to cultural activity is valid, of course, and sustainable populations of agriculturalists depended considerably upon extensive landscape modification, but cultural collapse did not occur frequently in Oceanic prehistory, nor was it correlated so sufficiently with deforestation as to sustain a general model.

\section{BEHAVIORAL ECOLOGY}

The explicit use of behavioral ecology in archaeology (analysis of observations about past cultural choices according to expectations of fitness), and especially of consumer choice or optimal foraging theory, began about 35 years ago in New Zealand (Anderson 1973) and California (Beaton 1973). It has flourished in American bioarchaeology (references in Grayson 2001, Kennett and Winterhalder 2006, Lupo 2007) but with some exceptions (e.g., Anderson 1981, 1983, Gosden and Robertson 1991, Anderson and Smith 1996, Nagaoka 2002a,b, Kennett et al. 2006) it has languished in Oceania. Nevertheless, the idea of human behavioral ecology has made a strong impression upon Pacific historical ecology, judging by the way in which five of the papers in this issue bounce their preferred interpretations off its precepts. Jones outlines environmental and archaeological research on the harvesting of marine resources in some of the Lau Islands, Fiji. Her findings are not in substantial agreement with a general hypothesis of marine resource depression on Pacific islands. Some data recorded an increase in fish size, and some shellfish availability declined, but overall the types and diversity of vertebrate and invertebrate species exploited over about 3,000 years changed relatively little. Jones argues that the Lauan marine exploitation system was stable and sustainable over a long period, reflecting a long-term, low-density human population. She observes that resource depression in the region is more a modern than a prehistoric phenomenon and that exploitation strategies in Lauan fishing and shellfishing are determined as much by cultural preferences as by harvesting optimization. Thomas argues similarly that overexploitation of marine resources, such as shellfish, was not common on atolls because of an abundance of resources relative to the small size of the consumer populations.

Des Lauriers' study of resource use on Isla Cedros, Baja California, elaborates the emerging theme. Archaeological data show that there was high diversity of taxa exploited throughout the prehistoric period, beginning in the early Holocene. Des Lauriers explicitly rejects the notion that harvesting diversity was a function of resource depression, preferring to see it as a response to instability in coastal ecosystems. He suggests that flexible, broadly based subsistence strategies, quite probably developed on continental margins and subsequently imported to islands, operated there from the beginning of habitation. Natural environmental change is also an important factor on Isla Cedros and perhaps more widely in Pacific Mexico; Des Lauriers argues that the impact of sea-level rise on Zostera meadows better accounts for the later Holocene disappearance of sea turtles from archaeological sites than human overexploitation. The burden of Des Lauriers' thoughtful discussion is that the consumer-resource relationship was rather more complex than is envisaged in optimal foraging theory and included mechanisms of community resource monitoring that acted to prevent, or sometimes actually to encourage, overexploitation.

In a detailed report on the Sanak Biocomplexity Project, Alaska, Maschner et al. also find that long-term resource depression is relatively scarce in the 6,000-year record. It 
occurs in shellfish exploitation, where harvesting of lower-ranked species increased, but shellfishing was not continuous, and its frequency was largely controlled by climatically restricted access to offshore resources. The latter show no substantial sign of resource depression, such as size-frequency changes, but rather fluctuating abundance approximately in synchrony with climatic changes. There seems to have been no longterm trajectory of trophic cascade, or "fishing down the food web" (Pauly et al. 1998) as some broad models of change in marine resources propose. In a direct reference to that idea, Erlandson et al., although acknowledging that plausible evidence of such impacts is readily available (Rick and Erlandson 2008), argue that the Island Chumash and their ancestors followed a broader approach to subsistence economics, at times exhibiting resource depression and movement down trophic levels and at other times fishing up the food web by emphasizing the exploitation of large pelagic fish and marine mammals. As in the Sanak Island data, the archaeological sequences disclose no single trajectory of change in trophic harvesting. Erlandson et al. attribute the strategic changes in part to relations of consumer choice but also to changes in technology and marine habitats.

Evidence of long-term stability, contrary trends, cyclic change, or complex harvesting strategies in subsistence patterning, discussed in these papers, implies issues about population control, intentionality, and conservation and also the role of climatic change at several scales of analysis in maintaining or altering the balance of harvesting opportunities in coastal environments (Allen 2003, Anderson 2004, 2008d).

The principles of optimal foraging theory have also underpinned a model of migration in Remote Oceania. This proposes that foraging focused continuously upon the most efficiently harvested resources (in that region: turtles, seals, large reef fish, giant clams and other large shellfish, flightless birds, and breeding seabirds) produced rapid growth of consumer populations leading to depression of preferred resources, pressure to broaden the dietary array, and early encouragement of serial migration, within and between islands, at low population densities (Anderson 1983, 1996, 2001, 2003a,b, Anderson and McGlone 1991, Anderson and Smith 1996; cf. Keegan 1995). A similar model has been proposed recently for the initial island colonization of Wallacea and Sahul more than 40,000 years ago (O'Connell and Allen 2007, Allen and O'Connell 2008, O'Connell et al. 2009). It is argued that migration from Sunda to Sahul occurred within only a few thousand years, perhaps faster, and that it was driven by technological development and territorial considerations, modeled in the Ideal Free Distribution paradigm, among coastally oriented colonists whose subsistence behavior created progressive marine resource depression. Summerhayes et al. doubt that hypothesis. They cite accumulating evidence of very early inland occupation in New Guinea and its offshore islands and argue that the initial colonists were not simply coastal. In addition, there is evidence that large terrestrial birds survived many millennia in contact with people, and that occasional evidence of changes in shellfish taxa and size frequency dates to 20,000 years after initial occupation. The implications are that resource exploitation and population remained at very low levels during the first modern human colonization of $\mathrm{Wal}-$ lacea and Sahul, that even if settlement was initially coastal there was a huge interior able to absorb any growth, and that, consequently, marine resource depression cannot be invoked as the impetus to migration.

These debates are far from being resolved, but clearly there is a challenge emerging to the general proposition that phenomena central to the concerns of historical ecology, such as changing patterns of prehistoric marine harvesting and maritime migration, can find sufficient explanation in behavioral ecology. The great virtue of behavioral ecology, of course, is that it is an openly systematic approach, warranted plausible a priori by explicit behavioral logic and an abundance of evidential demonstration in vertebrate and invertebrate case studies. Yet what constitutes a fundamental and satisfactory explanation of subsistence behavior in evolutionary ecology as a generality might be too simplistic for 
the behavioral flexibilities and emergent qualities of adaptation, social organization, and information transfer in long-term human behavior.

\section{LOOKING FORWARD}

Late-twentieth-century archaeological approaches to Pacific historical ecology, especially in Oceanic landscapes, focused on the role of anthropogenic environmental change because they were methodologically predisposed and well equipped to do so, and because the prevailing philosophy framed cultural-environmental transactions in that way. Recent research, including in the papers in this issue, is developing a more complex, and probably more realistic, perspective on the nature and operation of relationships in historical ecology, although it does not yet propose a broadly coherent narrative comparable with that in the anthropogenesis model.

In the area of introduced biota the conventional hypothesis of transported landscapes is open to question in evidential terms and lacks the kind of systematic protocol for analysis that might be adopted from the theory and methods of research in biological invasion. In addition, however, the archaeological perception of what happens when new biota are introduced to islands seems superficial in the light of known and suspected complexity of interspecies and transtrophic relationships in ecological networks. How networks react to disturbance, including to biological invasions, and which introduced or indigenous taxa decline or flourish, involves complex issues of endemism (Sadler 2001), linkage, abundance, and trophic generalization that need to be modeled more realistically (Montoya et al. 2006) before we can reach any profound understanding of relative similarity in cultural landscapes.

Similarly, explaining the histories of $\mathrm{Pa}$ cific cultural landscapes seems more complex now than had often been implied in propositions of anthropogenic transformation. Climatic change is emerging as an influential factor at various scales of analysis. Delivered through long-term movement in sea levels and coastal biomass distribution, climate is seen as constraining the overall shape of late Quaternary Indo-Pacific prehistory (Pope and Terrell 2008). Changes in wind patterns arising from millennial-scale variation in the incidence of El Niño successively widened and narrowed opportunities for eastward migration in Oceania (Anderson et al. 2006), changes in temperature over the last millennium or so affected the distribution of Polynesian subsistence opportunities (Allen 2003, 2006), and decadal-scale variation in fishing patterns could be related to the effects of sunspot activity on El Niño-Southern Oscillation frequency (Anderson 2008d).

Demographic histories are also likely to have been more variable than is commonly assumed. Malthusian assumptions, which often underlie models of behavioral ecology, are not broadly realistic. But then, neither might be equilibrium assumptions. A hypothesis of rapid, serial episodes of population growth and decline on Easter Island (Cole and Flenley 2008), which partly decouples the demography-deforestation equation that sustains cultural collapse ideas, is worth wider exploration. At the same time, among the papers in this issue there is argument for the long-term maintenance of fairly stable, lowdensity populations, including in areas not affected by major endemic pathogens such as malaria. Is this indicative of the efficacy of cultural methods of population control, and does that imply long-term ecological monitoring and resource-level conservation?

I am reluctant to think so but willing to be persuaded. Certainly, readdressing such venerable questions about demography and cultural agency, and others about climatic forcing, resource harvesting, and, indeed, processes of anthropogenic impact upon insular biotas, will produce a richer, subtler, and more complex understanding of Pacific historical ecology.

\section{Literature Cited}

Allen, J., and J. F. O'Connell. 2008. Getting from Sunda to Sahul. Pages 31-46 in G. Clark, F. Leach, and S. O'Connor, eds. Islands of inquiry: Colonisation, seafaring and the archaeology of maritime land- 
scapes. Terra Australis 29. Australian National University, Canberra.

Allen, M. S. 2003. Human impact on Pacific nearshore marine ecosystems. Pages 317325 in C. Sand, ed. Pacific archaeology: Assessments and prospects. Le Cahiers de l'Archeologie en Nouvelle-Caledonie 15, Noumea.

. 2006. New ideas about late Holocene climatic variability in the central Pacific. Curr. Anthropol. 47:521-535.

Anderson, A. J. 1973. Archaeology and behaviour: Prehistoric subsistence behaviour at Black Rocks Peninsula, Palliser Bay. M.A. thesis, University of Otago, New Zealand.

1981. A model of prehistoric collecting on the rocky shore. J. Archaeol. Sci. 8:109-120.

-1983. Faunal depletion and subsistence change in the early prehistory of southern New Zealand. Archaeol. Oceania 18:1-10.

- 1995. Current approaches in East Polynesian colonization research. J. Polynesian Soc. 104:110-132.

. 1996. Adaptive voyaging and subsistence strategies in the early settlement of East Polynesia. Pages 359-374 in T. Akazawa and E. Szathmary, eds. Prehistoric dispersal of Mongoloids. Oxford University Press, Oxford.

. 1997. Prehistoric Polynesian impact on the New Zealand environment: Te whenua hou. Pages 271-283 in P. V. Kirch and T. L. Hunt, eds. Historical ecology in the Pacific islands. Yale University Press, New Haven, Connecticut.

. 2001. Mobility models of Lapita migration. Pages 15-23 in G. Clark, A. Anderson, and T. Vunidilo, eds. The archaeology of Lapita dispersal in Oceania: Papers from the Fourth Lapita Conference, June 2000, Canberra, Australia. Terra Australis 17. Australian National University, Canberra.

- 2002. Faunal collapse, landscape change and settlement history in Remote Oceania. World Archaeol. 33:375-390.

- 2003a. Initial human dispersal in Remote Oceania: Pattern and explanation.
Pages 71-84 in C. Sand, ed. Pacific archaeology: Assessments and prospects. Le Cahiers de l'Archaeologie en NouvelleCaledonie 15, Noumea.

- 2003b. Uncharted waters: Colonization of Remote Oceania. Pages 169-189 in M. Rockman and J. Steele, eds. Colonization of unfamiliar landscape. Routledge, London.

- 2004. Islands of ambivalence. Pages 251-274 in S. M. Fitzpatrick, ed. Voyages of discovery: The archaeology of islands. Praeger, Westport, Connecticut.

. 2008a. The rat and the octopus: Initial human colonization and the prehistoric introduction of domestic animals to $\mathrm{Re}$ mote Oceania. Biol. Invas., DOI 10.1007/ s10530-008-9403-2.

- 2008b. Traditionalism, interaction and long-distance seafaring in Polynesia. J. Isl. Coastal Archaeol. 3:240-253, 268270.

- 2008c. Review of Bruce McFadgen: Hostile shores: Catastrophic events in prehistoric New Zealand and their impact on Maori coastal communities. Auckland University Press, Auckland, 2006. J. Pac. Hist. 43:393-394.

. 2008d. Short and sometimes sharp: Human impacts on marine resources in the archaeology and history of South Polynesia. Pages 21-42 in T. Rick and J. Erlandson, eds. Human impacts on ancient marine ecosystems: A global perspective. University of California Press, Berkeley.

Anderson, A. J., J. Chappell, M. Gagan, and R. Grove. 2006. Prehistoric maritime migration in the Pacific islands: An hypothesis of ENSO forcing. Holocene 16:1-6.

Anderson, A. J., and M. McGlone. 1991. Living on the edge: Prehistoric land and people in New Zealand. Pages 199-241 in J. Dodson, ed. The naive lands: Humanenvironmental interactions in Australia and Oceania. Longman Cheshire, Sydney.

Anderson, A. J., and I. W. G. Smith. 1996. The transient village in southern New Zealand. World Archaeol. 27:359-371.

Anderson, E. 1952. Plants, man and life. University of California Press, Berkeley.

Balée, W. 2006. The research program of 
historical ecology. Annu. Rev. Anthropol. 35:75-98.

Beaton, J. M. 1973. The nature of aboriginal exploitation of mollusk populations in southern California. M.A. thesis, University of California, Los Angeles.

Bedford, S. 2006. Pieces of the Vanuatu puzzle: Archaeology of the north, south and centre. Terra Australis 23, Australian National University, Canberra.

Colautti, R. I., I. A. Grigorovich, and H. J. MacIsaac. 2006. Propagule pressure: A null model for biological invasions. Biol. Invas. 8:1023-1037.

Cole, A., and J. Flenley. 2008. Modelling human population change on Easter Island far from equilibrium. Quat. Int. 184:150165.

Crosby, A. W. 1986. Ecological imperialism: The biological expansion of Europe, 9001900. Cambridge University Press, Cambridge.

Diamond, J. 2005. Collapse: How societies choose to fail or succeed. Viking, New York.

Dickinson, W. R. 2003. Impact of midHolocene hydro-isostatic highstand in regional sea level on habitability of islands in Pacific Oceania. J. Coastal Res. 19:489502.

Fosberg, F. R., ed. 1963. Man's place in the island ecosystem: A symposium. Bishop Museum Press, Honolulu, Hawai'i.

Gosden, C., and N. Robertson. 1991. Models for Matenkupkum: Interpreting a late Pleistocene site from southern New Ireland, Papua New Guinea. Pages 20-45 in J. Allen and C. Gosden, eds. Report of the Lapita Homeland Project. Australian National University, Canberra.

Grayson, D. K. 2001. The archaeological record of human impacts on animal populations. J. World Prehist. 15:1-68.

Hather, J. G., and P. V. Kirch. 1991. Prehistoric sweet potato (Ipomoea batatas) from Mangaia Island, central Polynesia. Antiquity 65:887-893.

Horrocks, M., and S. Bedford. 2005. Microfossil analysis of Lapita deposits in $\mathrm{Va}$ nuatu reveals introduced Araceae (aroids). Archaeol. Oceania 40:67-74.
Horrocks, M., and M. I. Weisler. 2006. Analysis of plant microfossils in archaeological deposits from two remote archipelagos: The Marshall Islands, eastern Micronesia, and the Pitcairn Group, Southeast Polynesia. Pac. Sci. 60:261-280.

Keegan, W. F. 1995. Modeling dispersal in the prehistoric West Indies. World Archaeol. 26:400-420.

Kennett, D. J., A. J. Anderson, and B. Winterhalder. 2006. The ideal free distribution, agricultural origins and the colonization of the Pacific. Pages 265-288 in D. Kennett and B. Winterhalder, eds. Behavioural ecology and the transition to agriculture. University of California Press, Berkeley.

Kennett, D., and B. Winterhalder, eds. 2006. Behavioural ecology and the transition to agriculture. University of California Press, Berkeley.

Kirch, P. V. 1982. The impact of the prehistoric Polynesians on the Hawaiian ecosystem. Pac. Sci. 36:1-14.

Kirch, P. V., and T. L. Hunt, eds. 1997. Historical ecology in the Pacific islands. Yale University Press, New Haven, Connecticut.

Ladefoged, T. N., and M. W. Graves, eds. 2002. Pacific landscapes: Archaeological approaches. The Easter Island Foundation, Los Osos, California.

Larson, G., T. Cucchi, M. Fujita, E. MatisooSmith, J. Robins, A. J. Anderson, B. Rolett, M. Spriggs, G. Dolman, T.-H. Kim, N. T. D. Thuy, E. Randi, M. Doherty, R. A. Due, R. Bollt, T. Djubiantono, B. Griffin, M. Intoh, E. Keane, P. Kirch, K.-T. Li, M. Morwood, L. M. Pedrina, P. J. Piper, R. J. Rabett, P. Shooter, G. Van den Bergh, E. West, S. Wickler, J. Yuan, A. Cooper, and K. Dobney. 2007. Phylogeny and ancient DNA of Sus provides insight into neolithic expansion in island Southeast Asia and Oceania. Proc. Natl. Acad. Sci. U.S.A. 104:4834-4839.

Lindenmayer, D. B., and J. Fisher. 2006. Habitat fragmentation and landscape change: An ecological and conservation synthesis. CSIRO Publishing, Australia.

Lupo, K. D. 2007. Evolutionary foraging models in zooarchaeological analysis: Re- 
cent applications and future challenges. J. Archaeol. Res. 15:143-189.

McFadgen, B. 2006. Hostile shores: Catastrophic events in prehistoric New Zealand and their impact on Maori coastal communities. Auckland University Press, Auckland.

Montoya, J. M., S. L. Pimm, and R. V. Sole. 2006. Ecological networks and their fragility. Nature (Lond.) 442:259-264.

Nagaoka, L. A. 2002a. The effects of resource depression on foraging efficiency, diet breadth and patch use in southern New Zealand. J. Anthropol. Archaeol. 21:419-442.

.2002b. Explaining subsistence change in southern New Zealand using foraging theory models. World Archaeol. 34:84102.

O'Connell, J. F., and J. Allen. 2007. PreLGM Sahul (Pleistocene Australia-New Guinea) and the archaeology of early modern humans. Pages 395-408 in P. Mellars, K. Boyle, O. Bar-Yosef, and C. Stringer, eds. Rethinking the human revolution: New behavioural and biological perspectives on the origin and dispersal of modern humans. McDonald Institute Monographs, Cambridge.

O'Connell, J. F., J. Allen, and K. Hawkes. 2009. Modeling Sahul colonization: Implications for the origin of seafaring. In A. Anderson, J. Barrett, and K. Boyle, eds. The global origins and development of seafaring. McDonald Institute Monographs, Cambridge. (in press.)

Pauly, D., V. Christensen, J. Dalsgaard, R.
Froese, and F. Torres Jr. 1998. Fishing down food webs. Science (Washington, D.C.) 279:860-863.

Pope, K. O., and J. E. Terrell. 2008. Environmental setting of human migrations in the circum-Pacific region. J. Biogeogr. 35:121.

Prebble, M., and J. Wilmshurst. 2008. Detecting the initial impact of humans and introduced species on island environments in Remote Oceania using palaeoecology. Biol. Invas., DOI 10.1007/s10530-0089405-0.

Rainbird, P. 2002. A message for our future? The Rapa Nui (Easter Island) ecodisaster and Pacific island environments. World Archaeol. 33:436-451.

Rick, T. C., and J. M. Erlandson. 2008. Human impacts on ancient marine ecosystems: A global perspective. University of California Press, Berkeley.

Rolett, B. 2008. Avoiding collapse: PreEuropean sustainability on Pacific islands. Quat. Int. 184:4-10.

Rolett, B., and J. Diamond. 2004. Environmental predictors of pre-European deforestation on Pacific islands. Nature (Lond.) 431:443-446.

Sadler, J. P. 2001. Biodiversity on oceanic islands: A palaeoecological assessment. J. Biogeogr. 26:75-87.

Stahl, P. W. 2008. The contributions of zooarchaeology to historical ecology in the neotropics. Quat. Int. 180:5-16.

Steadman, D. W. 2006. Extinction and biogeography of tropical Pacific birds. University of Chicago Press, Chicago. 
